\title{
Marking time among the Ch'orti' Maya: an expressive act of culture
}

Marcar el tiempo entre los mayas ch'orti': un acto cultural Marquer le temps chez les Mayas Ch'orti' : un acte culturel

\section{Kerry Hull}

\section{OpenEdition}

\section{Journals}

Electronic version

URL: http://journals.openedition.org/jsa/15134

DOI: 10.4000/jsa. 15134

ISSN: 1957-7842

\section{Publisher}

Société des américanistes

\section{Electronic reference}

Kerry Hull, « Marking time among the Ch'orti' Maya: an expressive act of culture », Journal de la Société des américanistes [Online], Maya times | 2017, Online since 31 December 2017, connection on 10 December 2020. URL : http://journals.openedition.org/jsa/15134; DOI : https://doi.org/10.4000/jsa. 15134 


\title{
Marking time among the Ch'orti' Maya: an expressive act of culture
}

\author{
Kerry HuLL*
}

The indigenous population of Ch'orti' Maya of southern Guatemala make use of many natural phenomena to identify and mark time. In this study I explain how Ch'orti' organize and define the time for ceremonial, agricultural, and other purposes through the careful use of astronomical calculations and observations. I also show how time is divided and conceptualized within a day, and the specificity of these divisions in Ch'orti'. Furthermore, I argue that various lengths of time are of special importance for Ch'orti' and dictate the duration of rituals, some of which could be based on corn farming cycles. Finally, I propose that several aspects regarding the notion of time among the Ch'orti' have their roots in the ancient Classic Maya period. [Key words: Maya, Ch'orti', time, ritual, Guatemala.]

Marcar el tiempo entre los mayas ch'orti': un acto cultural. El pueblo indígena ch'orti' maya del sur de Guatemala hace uso de numerosos fenómenos naturales para señalar y marcar el tiempo. En este estudio explico cómo los ch'orti' organizan y delimitan el tiempo para fines ceremoniales, agrícolas, entre otros propósitos, utilizando cuidadosamente cálculos y observaciones astronómicos. También analizo cómo el tiempo del día se divide y conceptualiza en ch'orti', poniendo de relieve las especificidades de dichas divisiones. Por otra parte, argumento que diversos espacios de tiempo son muy importantes para los ch'orti' y dictan la duración de rituales, algunos de los cuales podrían ser basados en los ciclos agrícolas del maíz. Por fin, propongo que varios aspectos del entendimiento de los ch'orti' acerca del concepto del tiempo tienen raíces en el período clásico de los mayas antiguos. [Palabras claves: maya, ch'orti', tiempo, ritual, Guatemala.]

Marquer le temps chez les Mayas Ch'orti' : un acte culturel. La population maya ch'orti du Sud du Guatemala fait usage de nombreux phénomènes naturels pour identifier et marquer le temps. Dans cette étude, j'explique comment les Ch'orti' organisent et définissent différents temps, en particulier ceux cérémoniels et agricoles, grâce à l'utilisation de calculs et d'observations astronomiques précis. J'analyse également les sous-divisions temporelles de la journée en Ch'orti' en montrant leurs spécificités. En outre, je soutiens que les Ch'orti' attachent une importance

* Brigham Young University, Provo, USA [kerry_hull@byu.edu]. 
particulière à certaines périodicités, lesquelles dictent la durée de rituels, et pourraient pour certaines être fondées sur les cycles de la culture du maïs. Enfin, je propose que plusieurs notions temporelles des Ch'orti' actuels trouvent leurs racines dans les conceptions anciennes des Mayas de la période classique. [Mots-clés : Maya, Ch'orti', temps, rituel, Guatemala.]

The Ch'orti' Maya of southern Guatemala make use of numerous natural phenomena to note and mark the passing of time. Much of the rich calendric and astronomical notations recorded among the Ch'orti' by Rafael Girard in the first half of the twentieth century have been lost; however, the Ch'orti' still organize and delineate time for ceremonial, agricultural, and other purposes based on careful astronomical calculations and observations. Drawing on my own data from over 30 months of linguistic and anthropological fieldwork among the Ch'orti', as well as that of other contemporary researchers working in the Ch'orti' area, I discuss the notions of time and time-related ritual in Ch'orti' society today, showing how time is divided and conceptualized, both at an abstract and specific level. Time-segmentation units, even within a day, have unique characteristics among the Ch'orti'. Furthermore, I discuss the cyclical and meteorological foundations of time and trace their mythological origins. Agriculture, especially the life-cycle of corn, as I argue, is the primarily anchor of temporality among the Ch'orti'; yet with that comes a perpetual instability as seasonal phenomena do not always adhere to strict timetables. Thus, the Ch'orti' employ ritual as the means of solidifying and managing temporal transitions as well as placating agricultural deities.

\section{The notion of "time"}

A questionable dichotomy commonly stated is that societies view time in one of two ways: linearly or cyclically (see Bloch 1977, p. 282). Sometimes it is a little of both. ${ }^{1}$ What should concern us more is how societies reckon or organize time, and the outward representations of that reckoning, such as in ritual and agricultural cycles. According to Clarke, "...the question of how time reflects and matters to society is more helpfully focused on differences in the organization of time, rather than on its conception" (2008, p. 10). Indeed, time often becomes codified when linked to regular ritual activity, as Durkheim (1912) and others have argued. We then need to look at the temporal reference points deemed relevant by societies and determine their bases or origins (e.g., meteorological, astronomical, etc.). Notions of time can also be intimately associated with space or specific locations. For example, in Yucatec Mayan,

1. For an enlightening discussion of this issue see Rice Prudence M., 2008, “Time, power, and the Maya", Latin American Antiquity, 19 (3), p. 275-298. 
"Events are seen to take place when ф'úk'učul 'uk'ìinil "their time has come", implying that they have temporal as well as spatial boundaries" (Hanks 1990, p. 391, orthography altered). Time and space are "the principle axes", according to Gossen (1974, p. 236), for narrating classes of events among the Tzotzil Maya of Chamula.

As time-reckoning is, at its heart, a social construct, it will therefore always be idiosyncratic to each society (Bloch 1977; Goody 1991; Lévi-Strauss 1966), as Durkheim (1912) alluded to more than a century ago with his concept of "social time." Conceptions of time are hostages to culture. So for the Yucatec Maya, "time" itself is conceived of as a road (e.g., b'ehelá 'e" "today" [lit., "road here"]) (Hanks 1990, p. 394). Counting time is also inextricably linked to individual cultures. The Maya numerical system was vigesimal (based on a counting of fingers and toes) instead of decimal like ours (Schele and Freidel 1990, p. 79). Any effort to unpack the notion of time for the Ch'orti' or any other indigenous tradition will similarly confront various disconnects from Western forms of thought. We need to problematize the understanding of "time" yet further. Rather than strictly delineating a singular notion of "time", often multiple conceptions of time coexist in a single society. For the Classic Maya people, current creation was said to have begun on a specific date (Aug. 11, 3114 BC), a date on which their current temporal configuration went into effect. However, Late Classic polychrome ceramics, numerous stone monuments, and cave inscriptions such as at Naj Tunich mention dates far into the past: before the 3114 creation date, or in mythological time or where "time" was not reckoned in the same fashion (see Stone 1995, p. 184). So, mythic time is distinguished both from other historical times and from current periodic time (Stuart 2011).

Concurrently, astronomical observations provided predictable, repetitive events upon which various prehispanic and contemporary Maya groups based their notions of time. The cyclic view of time that dominated ancient Maya thought was likely linked to visible astronomical continuities, or what could be termed "recurrent time". However, also readily apparent would be the presence of "advancing time", that is, the ever-changing lifecycle of living things. For instance, the ritual or tzolkin calendar of the ancient Maya consisted of 260 days, which, as Tate (1992, p. 13) has argued, likely derives from the human gestation period (9 lunations of roughly 29 days each).

Similarly, botanical cycles, i.e., sequences of periods, can often be linked metaphorically to concepts of progressive time (Clark 2008, p. 7, 17). The natural events of planting, growing, harvesting, and withering away were metaphorically connected to the life of a human being. According to Knab, such botanical metaphors were "voluminous" in Aztec culture (Knab 1986, p. 46). The Atiteco Maya refer to maize seeds that are to be used for planting as muk "interred ones" or jolooma "little skulls" (Carlsen and Prechtel 1991, 
p. 28). Furthermore, among the K'iche' Maya of Momostenango plant-human metaphors were common even before the child was born. The calendar diviner of the patrilineage would ritually "sow" (awex) and "plant" (ticon) the unborn child in his lineage shrine (Tedlock 1982, p. 271).

The process of human development and growth was also closely linked to botanical metaphors. The Proto-Mayan (pM) term *ri'ix "ripe(n), old (person)" and by extension "birth" is homophonous with the Proto-Yucatec word *yi'h "corn tassel", which makes the botanical connection even clearer (Justeson et al. 1988, p. 138, note 19).

For the Ch'orti' Maya botanical metaphors abound in relation to the lifecycle of humans, though this is just one of several ways the Ch'orti' organize their notions of time. Indeed, as I discuss below, multiple conceptions of Ch'orti' time coexist. Some are tied to invariable astronomical certainties, while others are associated with agricultural cycles which, while inherently less certain, are still sufficiently predictable to help locate and delineate periods of time.

\section{Time segmentation among the Ch'orti'}

The concept of "time" in Ch'orti' can be expressed best by the word k'in, which also means "day," "sun," "festival" or "ceremony." Indeed, across Mayan languages the notions of "time" and "day" are expressed with a cognate of $k^{\prime}$ 'in and therefore are linguistically and culturally related, often including the additional meaning of "festival" (León-Portilla 1988, p. 17, 20, note 3). Among the Ch'orti' sometimes the abstract form k'inar is used, as in the expression anumuy e k'inar, "time passes", or uk'inar "always". It is common practice, however, to use the Spanish "tiempo", or "time" when describing time in more general or abstract terms. Another way used by ritual specialists to talk about time in a broader sense is to employ a poetic couplet, a pairing of the terms "day" and "night". For example: Ch 'a'r a'syob' atz'i ya' tamar e silensyo diya, tamar e silensyo noche. "They are playing indeed in the silent day, in the silent night", meaning "They are playing all the time". As Hanks has shown for Yucatec Maya, the pairing of day and night is a metonymic emblem of time (Hanks 1989, p. 107).

2. The relationship between the concepts of "time" and the idea of "festival", both $k$ 'in (or a cognate of it in various Mayan languages) has a cultural logic in the Maya area. Vogt has noted that among the Tzotzil Maya of Zinacantan in Chiapas, Mexico that "one of the key domains of the culture is expressed by the word $K$ 'in which designates a period of time in which a regularly scheduled ceremony takes place" (Vogt 1969, p. 571). Thus, the expression of time is intimately associated with a ceremony, a notion that fully resonates in the Ch'orti' worldview. 
The Ch'orti' divide days into the following categories, which include nouns and verbal phrases, all of which come from my data:

\begin{tabular}{|c|c|c|}
\hline Ch'orti' Time Segment & Meaning & Notes \\
\hline ajwank'in & $\begin{array}{l}\text { "the morning, very early in } \\
\text { the morning through } \\
\text { to about } 1: 00 \text { p.m. }\end{array}$ & $\begin{array}{l}\text { Usually by } 3: 00 \text { or } 4: 00 \\
\text { a.m. one can refer to it as } \\
\text { this. lit. "standing-sun" }\end{array}$ \\
\hline sakch'i' & $\begin{array}{l}\text { "show the first hints } \\
\text { of light in the morning" }\end{array}$ & lit. "white-grow" \\
\hline mayruma & "be the first light of day" & (see mayi, "deceive, trick") \\
\hline sakojp'ix & "very early in the morning" & lit. "it has already dawned" \\
\hline sakojpa sajmi & "early this morning" & $\begin{array}{l}\text { lit. "it dawned earlier } \\
\text { today" }\end{array}$ \\
\hline sakojpa & "morning" & lit. "it has dawned" \\
\hline sajmi & $\begin{array}{l}\text { "all the part of the morning } \\
\text { that has passed up until } \\
\text { now" }\end{array}$ & \\
\hline namsi'x e k'in & "afternoon" & $\begin{array}{l}\text { lit. "the sun has now gone } \\
\text { out of sight" }\end{array}$ \\
\hline ch'uyujk'in & "noon, afternoon" & lit. "lift-sun", "raise-sun" \\
\hline orajk'in & "afternoon" & $\begin{array}{l}\text { (from Spanish hora, } \\
\text { "hour", and Ch'orti" k'in, } \\
\text { "day; time" also means } \\
\text { "lunch") }\end{array}$ \\
\hline yuxin ajk'in & "noon, midday" & lit. "middle day" \\
\hline numen k'in & "later in the afternoon" & lit. "passed by sun" \\
\hline t'erpa'rk'in & "late afternoon" & lit. "tilted sun" \\
\hline maxa'n "dusk" & dusk & $\begin{array}{l}\text { when it is } 50 / 50 \text { light and } \\
\text { dark }\end{array}$ \\
\hline tokto akb'are & "early part of the evening" & lit. "it is already night" \\
\hline ik'sib'a'r & "twilight" & (see ik'sijb'an, “dark") \\
\hline k'in max & $\begin{array}{l}\text { "the last vestiges of light } \\
\text { visible before darkness } \\
\text { takes over" }\end{array}$ & \\
\hline$a k b^{\prime} a r$ & "night" & lit. "night" \\
\hline akb'arera'r & "night" & \\
\hline yuxin akb'ar & "midnight" & lit. "middle night" \\
\hline
\end{tabular}

Fig. 1 - Ch'orti' time-segment terms in a 24-hour period. 
Of particular interest is the conception of sajmi, which means "all the part of the morning that has passed up until now", and so is highly relative to the time of its use. ${ }^{3}$ The term kone' $r$ differs from sajmi in that it has a more general sense of "all of today" at times or a more specific focus of "at this moment" "at others", depending on the context. Also, max k'in "the last vestiges of light visible before darkness takes over" is interesting since the Ch'orti' say that this light is not the sun, but another light called max $k$ 'in (lit. "decay-sun"), a concept unique as far as I know among Maya groups. It is also noteworthy that a large number of these terms directly relate to the position and movement of the sun (note the preponderance of terms with $k$ 'in, "sun") (see Hanks 1990, p. 394).

\section{Telling time}

The Ch'orti' are remarkably apt at judging the time, both during the day and at night, even without the use of modern time-telling devices. Girard also commented on this fact saying: "No usa reloj el chortí ya que conoce las horas del día con sorprendente exactitude guiándose por la posición del sol y las de la noche por el canto de diversas aves y la situación de las estrellas, que desde su tierna infancia ha aprendido a observar" ("The Chortí do not use clocks since they know the hour with surprising exactness guided by the position of the sun and those of the night by the singing of various birds and the situation of the stars, that they have learned to observe since childhood") (Girard 1949, p. 228). One of my consultants explained how the Ch'orti' tell time without the aid of modern-day watches ${ }^{4}$ :

We look at the sky where the moon is when it gets dark. And we know as it dawns, if we understand it, if it is the middle of the night, or we are in darkness, we look for the moon where it sits... And if we see the moon sitting in the middle of the sky, or if we see where it sits, we go with the moon, which we call 'katu'.' Now there it sits now and it is now telling us that we are in the middle of the night... if we know that it is now dawning, we also see the moon or a star. If we see the star when it dawns, we say this star is now low in the

3. A cognate form of this term appears in various Mayan languages. Vapnarsky has noted nearly identical semantics to the Ch'orti' term in the Yucatec term sáam. She writes: "Sáam is a hodiernal marker, indicating that the event referred to happened a certain time previously in the same day. More strictly, sáam expresses hodiernal remoteness within the day, a distance between topic time and the target..." (Vapnarsky 2016). An early possible hieroglyphic antecedent may appear on the Palace Tablet at Palenque at position Q10 in the expression sa-mi-ya HUL-li-ya, sahmiiy huliiy "earlier today it [the moon] arrived" (see Stuart et al. 1999, II:35).

4. While Ch'orti' men have watches today, most do not actually work. They are worn more as status symbols than practical devices. 
sky. Then we are knowing how to leave and travel... the star will indicate to us that it is now dawning... And with this, we measure how much is the path of the space of the night.

My consultant was clearly referring to Venus as the Morning Star, which usually appears around 3:30 a.m. in the spring and 4:00 a.m. in the fall, rising over the east and whose appearance is used to tell what time one should begin walking to one's cornfield. He continued explaining: "And thus it was like this the ancestors would work also, that when they didn't have watches... Thus in this way they used to know how much to work during the day... They wouldn't work just because they would also measure the sun, how much of the sun was passing. Thus it was for the night and thus they measured the day also." In this way the sun, moon, and stars have traditionally been the standard references for judging time for the Ch'orti'.

The Ch'orti' conception of time, both as an abstract notion as well as a measurable entity, is directly linked to ritual practice, but those rituals are likewise yoked to observable, natural phenomena, especially transcendent astronomical phenomena. The readily perceivable regularity of astronomical phenomena provides a reliable base for the development of a calendrical system, i.e., manifest hierophanies — as a means of recording and accurately predicting moments in time (see Hanks 2000, p. 244). Nilsson (1960) labels this type of time notation "time-reckoning," a system that judges time through actual observation of natural events and astronomical phenomena. For the Ch'orti', their concept of "calendar," which Nilsson would say is distinct from time-reckoning, is in fact derived from such observable astronomical phenomena that are codified through carefully observed ritual practice.

\section{The Ch'orti' calendrical system}

There is very little in the way of a traditional metadiscourse on the concept of a "calendar" among the Ch'orti' today. Two consultants, however, did provide some insight into the Ch'orti' view of a defined calendar in the following poetic couplet: uwirib'ir e ajk'in, uwirib 'ir e jab', "the sign of the day, the sign of the year". Uwirib 'ir derives from the root - ir "see", with the instrumental suffix - $i b$ ' and possessive markers $u$ - and -ir. Irib' means "sign" or "signal", something used for "seeing" or "determining". It is of interest that a similar expression is found in a Postclassic Maya hieroglyphic text on Lintel II of the Temple of the Four Lintels at Chichén Itzá: ta yilil k'in, ta yilil haabil, "On the sign of the day, On the sign of the year" (Figure 2, next page). Here also a possessed form of the root -il (cognate to the Ch'orti' -ir) is followed by $k$ 'in "day" and haab "year", suggesting a possible Postclassic period origin for this expression. 
Kerry HuLL

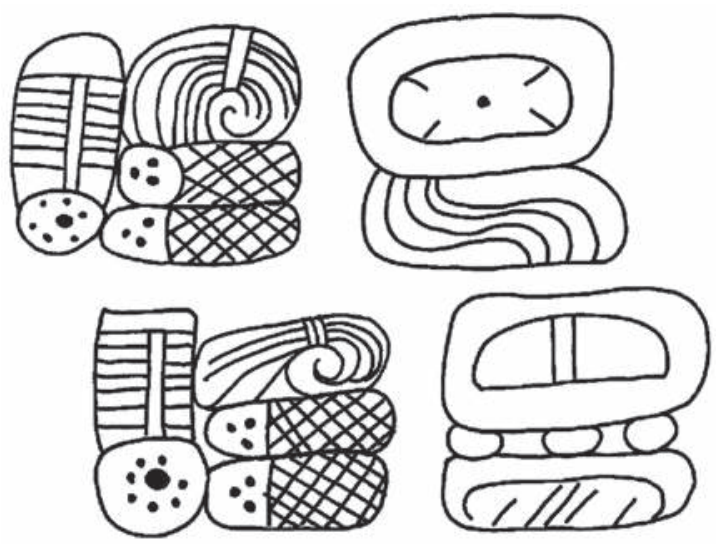

Fig. 2 - Lintel II of the Temple of the Four Lintels at Chichén Itzá: ta yilil k'in, ta yilil haabil, "On the sign of the day, On the sign of the year" (drawing by Asa Hull, after Ruth Krochok).

The only other overt definition of "calendar" is recorded by Girard (1949, p. 99) as "warin tzi q'in e dia e mes," a form given in the first-person by the Ch'orti' consultant, meaning "I am tzik'in-ing the day, the month". Tzik'in is the term for the Day of the Dead festival when the spirits of the dead return and are fed during an 8-9 day period. However, it is more likely here that a transcription error has occurred, and the original term was $t z i k-k$ 'in "countdays"; therefore, "I am counting the days and the months". Both Girard's and my consultants' definitions highlight the notation of days and months or years as a "calendar". 5

\section{Agricultural cycles and time}

"Systems of continuous time-reckoning," states Rice, "can be seen to arise out of socioeconomic needs. They are associated generally with more complex economic endeavors such as horticulture" (Rice 2008, p. 278). According to Girard, the Ch'orti' divide the year into two principal calendars, each with its own relevant numeric counts. One begins when the winter season ends at

5. The published work of Rafael Girard has clearly shown the Ch'orti' Maya also used a type of 260-day calendar system, which he justifiably refers to as a tzolk'in - the term applied to the ritual calendar cycle of the Classic period Maya. While some are quick to dismiss parts of Girard's work relating to larger Mesoamerican connections and origins, his data insofar as the Ch'orti' are concerned are in almost all cases unimpeachable in my view. After more than 16 years of working with the Ch'orti' I am constantly amazed at the accuracy of what he recorded, as well as its value for Ch'orti' studies. 
midnight on the 24th of October with the closing ceremony for the agricultural calendar and the start of the summer cycle. This date occurs almost exactly 260 days from the opening of the agricultural season, corresponding again very well to a Tzolk' in-type calendar. When the final act of the closing ceremony is held on October 25th, the Ch'orti' believe a new sun dawns the next day, this time called "Señor Sacramento" (Girard 1995, p. 320). Now a new numeric system of counting is instituted that differs from that of the rainy season.

The second is the Opening or "Invierno" (i.e., rainy season) Ceremony. Time is divided into units of 20 days during this season. The Ch'orti' call the 40-day period from February 8th to March 29th "the first forty", which is the time when the fields are cleaned of underbrush and prepared for planting (Girard 1995, p. 69). The first 20 days are for tree cutting and the second 20 days are for clearing brush.

It is the spring equinox that signals the next stage of milpa preparation-the burning of the fields. This next period is known as the "Second Forty" (ibid., p. 71). The termination of the Second Forty takes place on the all-important date of April 25th, the beginning of the opening ceremonies for the rainy season. These ceremonies continue through May 3rd. According to Girard's informants, the system of counting time changes after the rainy season begins, explaining that the "Reglamento del Invierno" is governed by the rainy season, which is different than that of summer. It now switches to a cycle of 180 days and counts of nine and thirteen. The numbers nine and thirteen are culturally significant spaces of time among the Ch'orti'. Girard notes that the Ch'orti' relate these time periods to the "Nine gods of the Night and Thirteen day gods who now act during a period of 9 nights and 13 days, respectively" (ibid., p. 95). The nine are agrarian deities who work at night to help the cultivating plants develop, and the thirteen are rain gods. One of Girard's consultants related the importance of the number nine as follows: "Every nine days the announcement of the rains must come with a clap of thunder; by this they (the gods) let us know that they are in agreement" (ibid., p. 177). This is why the Ch'orti' offer prayers to these Nine Gods every nine days so that it will rain every nine days like clockwork. While Wisdom states that the Ch'orti' do not attach much significance to the number thirteen, he does recognize that it is the number of sky deities and concedes thirteen probably "had ritual significance in the past" (Wisdom 1950, p. 429, footnote 94).

April 25th to May 3rd is the time of the rain-making ceremony ("great ceremony") (Wisdom 1950, p. 437). For the Ch'orti', this is also thought of as the "beginning of the year" when the rains come. So while the New Year according to the Western calendar is accepted and celebrated by the Ch'orti', they originally marked the beginning of the social, economic, and religious "New Year" on April 25th, corresponding to the onset of the rainy season and the accompanying rites (Wisdom 1950, p. 462). 


\begin{tabular}{|c|c|c|}
\hline $\begin{array}{l}\text { Astronomical and } \\
\text { meteorological phenomena }\end{array}$ & $\begin{array}{l}\text { Agriculture } \\
\text { labor }\end{array}$ & Calendar \\
\hline $\begin{array}{l}\text { First movement of the sun. } \\
\text { (Start of the visible solstice). } \\
\text { Winds. Rainy season. }\end{array}$ & $\begin{array}{l}\text { First work in the field. } \\
\text { Measuring the crop field. } \\
\text { Defloration. Cut low weeds. }\end{array}$ & 8 February. \\
\hline $\begin{array}{l}\text { Equinox. Descent of Solar } \\
\text { Deity. Heat. }\end{array}$ & $\begin{array}{l}\text { Burning of the weeds. } \\
\text { Smoke from the field } \\
\text { attracts the rains. }\end{array}$ & $\begin{array}{l}20 \text { March or Holy Week. End } \\
\text { of the "first forty". Beginning } \\
\text { of the "second forty". }\end{array}$ \\
\hline $\begin{array}{l}\text { First pass of the sun through } \\
\text { its zenith, determinant } \\
\text { of the first rainy season. } \\
\text { End of the summer cycle. } \\
\text { Significant position of the } \\
\text { Pleiades and stars. }\end{array}$ & $\begin{array}{l}\text { Avian sacrifice in the } \\
\text { cornfield. } \\
\text { Planting of the corn. } \\
\text { First weeding. }\end{array}$ & 30 April or 1 May. \\
\hline $\begin{array}{l}\text { Summer solstice. Time } \\
\text { of maximum precipitation. }\end{array}$ & Second weeding. & 21-22 June. \\
\hline $\begin{array}{l}\text { Position of the Milky Way } \\
\text { signals the "canícula" } \\
\text { or dog days. Dry weather. }\end{array}$ & $\begin{array}{l}\text { Preparation of the ground } \\
\text { for the second crop. }\end{array}$ & 25 June. \\
\hline $\begin{array}{l}\text { Second pass of the sun } \\
\text { through its zenith. Time of } \\
\text { maximum precipitation. } \\
\text { Change in the starry } \\
\text { landscape. }\end{array}$ & $\begin{array}{l}\text { Second planting of the } \\
\text { cornfield and folding down } \\
\text { of the first crop. }\end{array}$ & 12-13 August. \\
\hline Equinox. Strong rains. & $\begin{array}{l}\text { End of the clearing } \\
\text { of weeds of the second } \\
\text { planting. }\end{array}$ & 22-23 September. \\
\hline $\begin{array}{l}\text { End of the rainy season. } \\
\text { Change in the stars. }\end{array}$ & $\begin{array}{l}\text { The second crop is } \\
\text { changing into ears of corn. }\end{array}$ & $\begin{array}{l}24 \text { October at midnight. } \\
\text { End of the agricultural } \\
\text { cycle. }\end{array}$ \\
\hline $\begin{array}{l}\text { The new sun. The summer } \\
\text { cycle begins. }\end{array}$ & $\begin{array}{l}\text { Hunting, fishing, } \\
\text { harvesting. Rest. }\end{array}$ & $\begin{array}{l}25 \text { October in the morning. } \\
\text { The festive cycle and rest } \\
\text { for } 100 \text { days begins. }\end{array}$ \\
\hline Winter solstice. & Public festivals. & 21-22 December. \\
\hline
\end{tabular}

Fig. 3 - Correlations of astronomical and meteorological phenomena with Ch'orti' field labors and their dates (adapted after Girard 1962, p. 328).

\section{Time and celestial bodies}

The end of these ceremonies on May 3rd marks the beginning of the planting season. The field preparation that began on the spring equinox terminates 
at the opening of the winter planting season, which is also directly linked to astronomical phenomena. For example, the Ch'orti' watch the Pleiades in April to know when to start the winter ceremonies prior to planting. In Ch'orti' the Pleiades are known as mormorek' (lit. "conglomeration of stars") or siete cabritas in Spanish. Ch'orti' elders note that the Pleiades "change position (on the 25th of April) and appear in the east around ten o'clock at night" according to Girard. Girard continues: "Isidrio Benito Pérez manifiesta que a fines de abril las Cabrillas "vienen de vuelta" y siguen la carrera del sol; aparecen de madrugada por el "saliente", (oriente). Al brillar el sol "se van las Cabrillas a trabajar, y esta es la seña que tenemos para que los hombres, también vayan a sus labores" ("Isidrio Benito Pérez states that at the end of April the Cabrillas "come and go" and follow the path of the sun; they appear in the morning in the "east"...As the sun shines the Cabrillas "go to work and this is the sign we have that men also should go to their labors") (Girard 1995, p. 100).

The positions of certain constellations are also indicators of meteorological phenomena for the Ch'orti'. The Southern Cross is one of two crosses that are said to appear in the sky in May in the Ch'orti' area. One of my consultants described the two visible crosses as follows: "There is a small one and a large one. The large cross is the one that passes in the middle of the year and that we call the month of May. In the month of May we see the cross if it is standing up, like last night, in the month of May." When the Southern Cross retrogrades ("al doblar"), it is a signal that rain is coming, according to Ch'orti' elder Inés Díaz (Girard 1995, p. 100).

\section{The sun}

The sun, k'in or katata' (lit. "our father"), is one of the primary Ch'orti' deities and is spoken of as an animate being (Metz 2006, p. 124). Fought and Girard note that the Ch'orti' pray to the sun early in the morning (5:00 am according to Fought) just as the beams of the sun are starting to "push away the dark" (Fought 1972, p. 527, note 34.5). "That is the time they can pray to it for whatever they want to pray for", states Fought's consultant Isidrio González (Fought 1972, p. 489). The daily movements of the sun are said to be compared to the life cycle of a human being in that "the sun passes through different ages in one day and also during the annual cycle. They believe the sun is born at dawn, grows until midday, when it reaches its fullness, and dies at sunset" (Girard 1995, p. 318). The sun also plays a pivotal role in indicating the time for the onset of the rainy season and planting. ${ }^{6}$ Solstitial positions are used to judge the start and finish of the rainy season in relation to sunrises and

6. The name of the sun, Katata', according to López García and Metz (2002, p. 202), can also be a term for "la bendición" (lit. the blessing), i.e., the rains, or the clouds (tokar). 
sunsets. Esteban Peréz, a Ch'orti' elder of the town Tutikopot, noted that the Sun God is sometimes known as "The Seven" and is a deity who needs to be "impressed" by ceremonial formulas to come down to fertilize the earth as a fertility god (Girard 1995, p. 58-59). When the sun passes through the zenith, the principal Ch'orti' Fertility God, who is himself an aspect of the Sun God, penetrates the earth from the "very middle" of the sky, thereby impregnating the earth and making it fertile for cultivation" (ibid.). This God takes on the name of "The Seven"- a title specific to the Sun god-, appearing in longer appellations such as "El Señor de las Siete Pilas, de las Siete Palabras divinas, de los Diete imaginarios (sic), de los Siete Oidores del mundo, de las Siete disposiciones" ("The Lord of the Seven Fountains, of the Seven divine Words, of the Seven Imaginaries (sic), of the Seven Listeners of the world, of the Seven Dispositions" (Girard 1962, p. 48; 1995, p. 59). The Ch'orti' even say that from "his celestial abode to the earth there are only seven steps" (Girard 1995, p. 59). Traditional healers today regularly invoke the Sun God using the titles for him that include the number seven.

The sun is also vitally important in establishing and marking reference points of time. The spring solstice is a signal to begin clearing the fields for planting. The passing of the sun through its zenith on April 25th marks the moment the Fertility God fertilizes the earth for planting (Girard 1995, p. 58-59). The sun is not a singular deity for the Ch'orti'. It is a polymorphous entity that can assume various titles, names, and aspects, something that has clear Classic period antecedents. For example, a Classic-period image from the Central Tablet of the Temple of the Sun at Palenque shows the face of deity GIII as the Jaguar God of the Underworld. GIII is both a solar deity and a fire god when he appears as the Jaguar God of the Underworld (Figure 4a). Similarly, on Tikal Stela 31 a portrait of the Jaguar God of the Underworld shows clear characteristics of the Sun God with the cruller on his mouth and the $k$ 'in "sun" sign in his cheek (Figure 4b). Just as the Sun God could have multiple facets or manifestations during the Classic period, so the sun for the Ch'orti' had numerous monikers and alter-egos, including being equated with San Antonio, the Fire God. For example, one elderly healer I worked with told me she got her power from the "Sun" San Antonio when she walked over hot coals in her dream, by which she meant the Sun God in his aspect as the Fire God.

John Fought has also noted the various names the Sun God has in Ch'orti' thought: "They say that the Sun has not just one name. The one which he is best known by people continues to be Jesus Christ. They say that when it is just getting light its name is Child Redeemer of the World. One name is San Gregorio the Illuminator. ${ }^{7}$ One name is San Antonio of Judgment. One name

7. In the name "San Gregorio the Illuminator", "Illuminator" is ajtz'ab'tesyaj in Ch'orti', which refers to the idea of a mild, reflective, early morning light, and so would assumedly be one of the stations in the early morning (see Fought 1972, p. 527, note 34.17). 


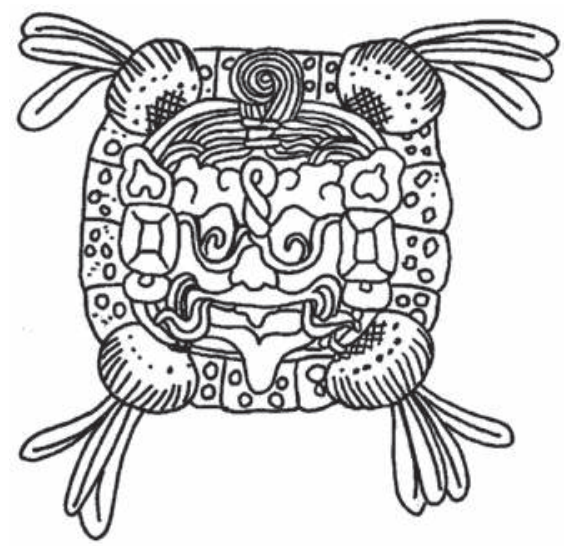

Fig. $4 \mathrm{a}-$ Central Tablet of the Temple of the Sun at Palenque depicting GIII as the Jaguar God of the Underworld (drawing by Asa Hull, after Linda Schele).

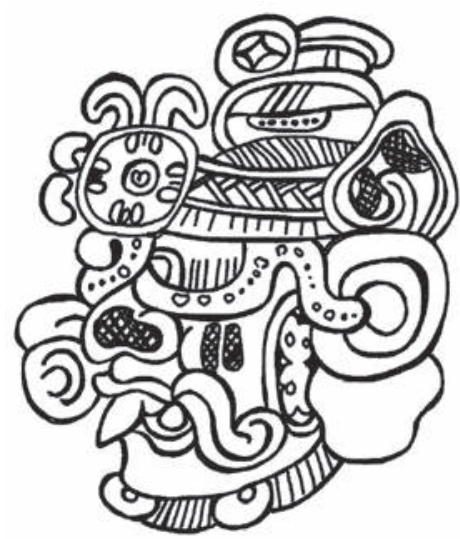

Fig. 4b - Jaguar god of the Underworld characteristics on the portrait of the Sun God on Stela 31, Tikal (drawing by Asa Hull, after Linda Schele).

is Child Guardian. One is Child Refuge. One is Child San Pascual. One is Child Succor. One is Child Creator. They say that at each hour, one of these is its name" (Fought 1972, p. 485). Thus, each hour in the day corresponds to a different name of the Sun God. One of my consultants described them as "positions" that the sun arrives at where it takes on the subsequent identity. Girard's consultants similarly noted that the sun's "positions may be multiple" (Girard 1995, p. 59). The specific names of the sun given by Fought's consultant were "given in a fixed order by Damasio López," but Fought's own consultant González "knows only that the Redemptor comes first, before the actual sunrise" (Fought 1972, p. 527, note 34.6-7).

The exact order of all the names associated with the individual stations have long been forgotten by most Ch'orti' today, but the names themselves live on primarily in healing prayers. Nowadays Ch'orti' healers, known as ajk'in, ajniroj, ajnirom, and ajnirum, ${ }^{8}$ commonly petition Katata' when asking for divine assistance in determining the afflicting illness or in curing the individual. Healers have a large number of names they recite at times, all of which are aspects of the Sun God - only a small portion of which were noted by Fought in the above-given quote. Others that I have recorded include San Gregorio,

8. An ajk'in is focally a diviner, but the word can also be applied to healers. The standard word for healer is ajnirom and less commonly ajniroj. Another term for "healer" is ajtz'akoner, which refers more generally to non-spiritual healers, such as medial doctors (see Metz and López García 2002, p. 210). 
Niño San Gregorio, Niño San Gregorio de Cristo, Niño San Antonio Revistador Pastoreador, Niño Revistador del Mundo, Niño Jesus, Padre Jesus, and more than a dozen more in healing prayers. Healers $\left(a j-k^{\prime} i n\right)$ especially petition the sun $\left(k^{\prime} i n\right)$ because of the intimate link the sun has to sorcerers and healers, i.e., those who divine. Wisdom has noted that "the god of the sun and light, of knowledge, and of magical power" shares the same name ajk'in, and so is the patron to healers, sorcerers, and diviners (Wisdom 1950, p. 399).

It is also notable that in Ch'orti' thought the rain gods (which are numerous) transform into sun gods after the rainy season ends and the summer cycle begins. Thus, solar deities are the alter egos of the rain gods (Girard 1995, p. 329).

\section{Production and petition of rain}

Timing is everything when it comes to planting corn for the Ch'orti' Maya. Farmers must be assured that the rains will come on time so that their investment of time and resources in planting their fields produces sufficient returns. Among the Ch'orti' is a class of ritual specialists who have the authority to petition the gods and angels of the Ch'orti' pantheon for the rains to come on a specific date. ${ }^{9}$ They are known as padrinos, ajk'ajpesyaj or ajk'ajtjaja'r (lit. "he who prays for rain"). They can be wrong about the date the rain falls, indicating their role is not to directly control the rains, rather they have the ritual knowledge of proper prayers and ceremonies to approach deities and petition their help. Frustration results both for the padrino as well as the people when the rains do not come on the specified day. In some cases, the people rise up against the padrino, as they did with Francisco Díaz García, one of the most famous padrinos of the last century, who was murdered when he failed to predict the right time for the rains. Because of his fame and tragic fate his story is still commonly being told in Ch'orti' hamlets today. What is important to note is that the Ch'orti' relate the falling of the rain on a specific date between April 25th and May 3rd as the convergence of several elements: the Southern Cross moving in the sky, the sun passing its zenith on the 25th when the Fertility God descends to fructify the soil, and the determined ritual efforts of padrinos to ask (or $u k$ 'ajb ' $u$ 'remind" as they sometimes describe it) the gods to release the rains.

The living natural world also informs the Ch'orti' on proper times for planting. As noted earlier, Girard commented on how the Ch'orti' use birds to

9. Today padrinos operate clandestinely due to fear of being labeled a "brujo" ("sorcerer)" (Hull 2003, p. 48-49). While in my fieldwork I have not encountered any practicing padrinos, in Jocotan, according to Metz (2006, p. 126-127) there are "a few underground padrinos" and some others in various aldeas (Metz pers. comm. 2008). Also, López García resided in the aldea of Tunucó Abajo with don Isidrio, whom he describes as a "Padre de Invierno y curandero" ("rain-bringing priest and healer") (López García 2003, p. 14, 236, 347-348; López García 2010, p. 85). 
help tell the time. Many birds also tell the Ch'orti' the time of coming rains (Girard 1949, p. 228). One of the surest signs that the rains are coming is when the orioles (chorcha) begin to build their nests. Therefore, the Ch'orti' use this as a sign that it is time to plant the milpa. Also, swallows or swifts are those who uk'ajtyo'b' e jaja'r or "piden el invierno" ("ask for the rains", invierno referring to "rainy weather" or "rainy season" among the Ch'orti') when they are seen flying lower than their typical high altitudes during a light rain. This is one of the signs for the Ch'orti' that it is time to plant corn in the milpa in the spring. They are thus known as "padrinos," just like rain-making priests. In addition, the plain chachalaca (Ortalis vetula) is also said to sing to announce the rains around April 1st and to indicate that it is time to plant the milpa.

\section{The Moon: goddess of rain}

Like the sun, the moon, or katu' (lit. "our mother"), is also closely linked to the production of rain. The moon therefore is religiously observed to determine the time of the coming of the rains. Starting in March through April 15th the moon gives certain signs whether the rainy season is set to begin or not. If the moon appears " $t$ 'erer" or "tilted" in the sky it means that the rains will be coming on time ("uk'eche e jaja'r e katu' t'erer ch'u'r," "the moon hanging tilted brings the rains"). However, if the moon is " $k$ 'atar" or "level" in the sky it means that the rains will be late ("ma uk'eche e katu' tu'k'atarir ch'u'r," "the moon in its level state doesn't bring (the rains)" (see Hull 2000). Additionally, in April if the new moon has a red glow ("Tya' topop e katu' yi utares e tokar chakchak tu't" ( "cuando es luna nueva y ella trae la nube roja en el rostro"), it is a sign that the rains will not be on time (see COIMCH 2004, p. 49-50)

The moon figures prominently in numerous aspects of Ch'orti' daily life relating to the proper timing of events. The moon is the patron of childbirth and women, and it is closely connected to rain. The Ch'orti' say that when the moon is tilted in the sky while waxing, it is like a jug of water that is pouring out its sacred liquid upon the earth. Being the patron of women, the menstrual cycles of women are also said to be timed according to the moon. When the moon is full, women too are "full", and begin three days of menstruation, i.e., "pouring", just like the moon does when it pours out its sacred substance (see Wisdom 1950, p. 299; Girard 1949, p. 196). A woman's menstruation is referred to as mok, a "sickness", but a specialized expression also exists, $u-y$-ich e ixel, which literally means "sap of Ixel", Ixchel being a term for the moon goddess in the Yucatan (Wichmann 1999, p. 119).

Many events are timed according to phases of the moon. The moon has a certain degree of control or influence over plants, so in order to ensure proper growth or results the Ch'orti' meticulously observe these traditions (see Palma 
Ramos 2001, p. 92). As Wisdom notes, "All useful trees, especially fruit trees, are said to belong to her [the Moon] and to receive their productivity from her" (Wisdom 1950, p. 400). For example, the Ch'orti' say that a seed has its best chance to germinate four days before or after the moon begins waxing. Girard similary notes that "Agricultural rules established in accordance with the position of the moon are invariably observed by the Chortís; theoretically planting four days before to four days after a lunar phase, preferably during the quarter moon" (Girard 1949, p. 234, my translation). The only exception to this is the planting of corn. Today there is near total agreement that during a waxing moon it is the best time to plant corn since the roots will be deeper and stronger, but the closer to the full moon the better. You can plant corn when the moon is waning, but the corn will not turn out well (Palma Ramos 2001, p. 142). According to Metz (2006, p. 130), both corn and beans "are planted when the moon is still 'young and tender' so that it does not 'burn' the seeds." The biggest fear is planting during the new moon, which they say is the worst thing one could do because the roots will not become strong, so one has to wait until three or four days after the new moon. ${ }^{10}$ Similarly, other plants such as the piñuelo (Bromelia pinguin) must be planted three days before a full moon (COIMCH 2004, p. 55).

The cutting of plants is also conspicuously timed to the phases of the moon. Grass for roof thatching can be cut when the moon is 14 days old. The Ch'orti' also wait until a full moon before cutting reed plants. As one of my consultants noted, "E katu' oraj ma'chi uyub'i kaxuri e pojp porke' asatpa", "The moon is waning and one cannot cut the tule because it will ruin". In general, if you cut plants when there is a new moon, they say the fruit will not come out well, and it could damage other plants too if you try to cut even one. Two days after is still rather dangerous, so waiting until four days after is usually advised. Even trees are said to die if cut during the final stages of a waning moon (COIMCH 2004, p. 56). Similarly as Metz (2006, p. 130) has noted, "Maguey also must be cut when the moon is 'growing' (like a gourd filling with water) so as not to dry and stunt the plants." There are also prohibitions against cutting wood for house construction during a new moon "ya que fácilmente es afectada por los comejenes y gorgojos" ("since it is easily affected by termites and weevils") (COIMCH 2004, p. 54). ${ }^{11}$ For the Ch'orti', cutting during a full moon is the best way to insure that wood lasts.

10. Corn plants are said to be "weak" during a new moon among the Ch'orti'. The moon can have a similar influence on humans in other Maya societies. Among the Kaqchikel Maya, according to Hinojosa, the moon's "weakness" is said to be "matched by a bodily weakness. The body is in a more delicate state; it is more susceptible to accident and injury and will bleed much if cut" (Hinojosa 2002, p. 36).

11. Both among the Mopan Maya and Q'eqchi' Maya of Belize the custom persists of not cutting palm during a new moon, though it is not always adhered to (see McSweeney 1995, p. 168). 
At the end of the agricultural cycle, harvesting ${ }^{12}$ is also carefully timed with the phases of the moon to avoid such activities during a new moon: "For harvesting of maize and cutting of sorghum and beans, it should not be done during a new moon", which if not respected will result in weevils eating holes in them (COIMCH 2004, p. 54, my translation). ${ }^{13}$

Personal activities are also timed according to specific phases of the moon. The period during a new moon is an especially perilous time for certain activities. One cannot bathe during this time because the water is contaminated for this three-day period. The Ch'orti' also say that when the new moon is not visible it is "taking a rest" with the sun, i.e., the moon and sun are having sex. Therefore, many Ch'orti' today abstain from sexual relations during a new moon because they say the child will be born with defects due to their "descuido" ("careless behavior"). This space of time is reserved only for the sun and moon. However, other Ch'orti' say that having sex during a new moon is a good way to guarantee one will have a baby since the moon "gives birth" during that time too. They say that from the third day to the seventh day they can have sex safely, and that this is a good time if the couple wants a baby. However, on the eighth day when the moon was at its half point it was dangerous again. The best situation for having sex is said to be from the tenth day to the fifteenth, closest to the fifteenth being the best when the moon is full to insure your child is fully developed (see Metz 2006, p. 137). Girard similarly notes: "El coito está también normado por reglas estrictas: debe practicarse durante la luna llena para que crezca la prole" ("Intercourse is also regulated by strict rules: it should be practiced during the full moon so that the offspring grows") (Girard 1949, p. 192). The perceived positive effects of the full moon on agriculture are likely extended here to human growth.

\section{Sacred numbers and time}

Other aspects related to marking time among the Ch'orti' are found in specific periods of days that have ritual or cultural importance. In addition to the nine and thirteen days mentioned earlier, another ritually and culturally significant space of time is eight days for the Ch'orti'. The timing of eight days ${ }^{14}$ pervades ritual practice and numerous aspects of daily life. Wisdom has noted that eight is

12. The Q'eqchi' Maya of the Guatemalan highlands also time the harvest of corn according to the proper phase of the moon (Johannessen 1982, p. 192).

13. In Tlaxcala in Central Mexico the phase of the moon is also believed to be directly related to the coming of pests at planting time (Altieri and Trujillo 1987, p. 206).

14. While it could be possible that the importance of the time period of eight days may have been influenced by the Spanish, there is clear evidence among the Ch'orti' that "eight" is intimately associated with corn through the maize cycle (see discussion below). 
Kerry HuLL

"important in the transition ceremonies especially and figures in nearly all ritual observances" (Wisdom 1950, p. 429). There a dozens of examples of eight-day periods among the Ch'orti'. For instance, the space of the opening ceremony of winter from April 25th to May 3rd is eight days. Also, the ceremony to the wind gods is enacted eight days after planting just as the corn and beans are sprouting (ibid., p. 444; see Girard 1949, p. 311). Padrinos, or rain priests, have to abstain from sex for eight days before or after carrying out a ceremony or it will be of no effect (Wisdom 1950, p. 435, 438). What is more, farmers must abstain from sexual relations eight days before planting or their fields will be attacked by disease and not grow properly (ibid., p. 441). The festival after a funeral goes on for eight days. The spirit of the dead (xerb'aj) remains around the household for eight days after its death (ibid., p. 403-404). Fasting during transitional rite ceremonies is done for eight days, during which time families eat only maize products (ibid., p. 435). Girls mark their first menses by fasting for eight days, all the while only eating maize products (ibid., p. 290). The birth festival for new mothers also lasts eight days, during which time the family only eats foods made from maize (ibid.). Furthermore, newlyweds cannot eat for eight day - except maize products - after their wedding ceremony (ibid., p. 300). Why are only maize products consumed during these various types of fasting for periods of eight days? The answer may lie in the fact that the number eight is closely linked to maize in Ch'orti' thought inasmuch as that is the exact number of days needed for a planted maize kernel to sprout, as all Ch'orti' readily recognize. Furthermore, as Girard has noted before, this could account for the Classic period association of the number eight with the head of the Maize God (Girard 1995, p. 194-195). The head variant of the glyph representing the Foliated Maize God

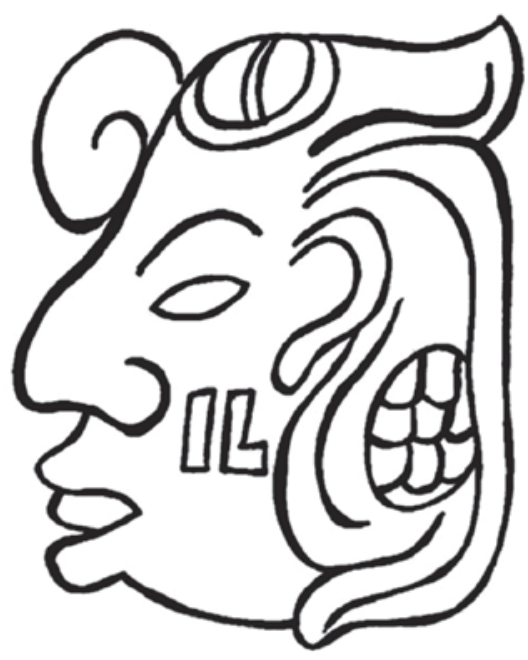
in the Classic period read WAXAKAJAN, lit. "eight-fresh ear of corn" (see Zender 2014, p. 2) (Figure 5). Spanning from the Classic period to the modern Ch'orti', the intimate connection between corn and the number eight has certainly stood the test of "time".

Fig. 5 - The glyph for the Foliated Maize God, read WAXAK-AJAN, lit. "eight-fresh ear of corn" (drawing by Asa Hull, after Mark Zender). 


\section{Conclusion}

In summary, the reckoning of time by the Ch'orti' is tightly bound to astronomical and meteorological phenomena. In particular, the sun, in all of its many manifestations, is crucial in determining reference points for ritual and social activity. Solstices and movements of the sun through its zenith have traditionally been carefully noted by the Ch'orti', though this is less so the case today. The sun through its multiple identities dominates the Ch'orti' pantheon and serves as the principal means of marking units of time. As I have also shown, the moon is also crucial, particularly for determining the coming of the rains for planting and regulating a plethora of daily activities. The Ch'orti' see these natural phenomena themselves as reliable reference points of time, yet they fully recognize that some of these events are fickle. Indeed, delineated time for the Ch'orti' is viewed as cyclical, as it was for the ancient Maya (Aveni 2000, p. 217), but precariously so. The need for human intervention in the form of prayers (or "reminders" to the gods as the Ch'orti' describe it) and ritual actions exists to assure certain natural and supernatural phenomena occur on "schedule", showing that such cycles of time occasionally need a "push" to continue in proper motion.*

* Manuscrit reçu en juin 2015, accepté pour publication en octobre 2016.

This article is part of the Special issue Measures and textures of time among the Maya: the said, the written, and the lived.

\section{References cited}

Altieri Miguel and Javier Trujillo

1987 "The Agroecology of corn production in Tlaxcala, Mexico", Human ecology, 15 (2), p. 189-220.

Aveni Anthony F.

2000 Empires of time: calendars, clocks and cultures, Tauris Parke Paperbacks, New York.

BLOCH Maurice

1977 "The past and the present in the present", Man (N.S.), 12 (2), p. 278-292.

CARLSEn Robert and Martin Prechtel

1991 "The flowering of the dead: an interpretation of Highland Maya culture", Man, 26 (1), p. 23-42.

Clarke Katherine

2008 Making time for the past: local history and the polis, Oxford University Press, Oxford.

DURKHEIM Emile

1995 [1912] The elementary forms of religious life, Free Press, New York. 
Kerry HulL

Fought John G.

1972 Chorti (Mayan) texts (1), University of Pennsylvania Press, Philadelphia. GIRARD Rafael

1949 Los Chorti ante el problema Maya, vol. 1, Antigua Librería Robredo, Mexico.

GIRARD Rafael

1962 Los mayas eternos, Antigua Librería Robredo, Mexico.

GIRARD Rafael

1995 People of the Chan, translated by Bennett Preble, Arizona Continuum Foundation, Chino Valley.

Gossen Gary

1974 [2 éd.] "To speak with a heated heart: Chamula canons of style and good performance", in Richard Bauman and Joel Sherzer (eds.), Explorations in Ethnography of Speaking, Cambridge University Press, Cambridge, p. 398-416.

Goody Jack

1991 [1968] "Time: social organization", in David L. Sills (ed.), International encyclopedia of social sciences 16, Macmillan, New York, p. 30-42.

HANKS William F.

1990 Referential practice: language and lived space among the Maya, University of Chicago Press, Chicago.

HANKS William F.

2000 Intertexts: writings on language, utterance, and context, Rowman and Littlefield, Lanham, MD.

Hinojosa Servando Z.

2002 "The hands know" bodily engagement and medical impasse in Highland Maya bonesetting", Medical Anthropology Quarterly, 16 (1), p. 22-40.

Hull Kerry

2000 Cosmological and ritual language in Ch'orti' [on-line], Report submitted to the Foundation for the Advancement of Mesoamerican Studies, Inc. (FAMSI), http://www.famsi.org/reports/hull/hull.htm, accessed on March 12, 2015.

Hull Kerry

2003 Verbal art and performance in Ch'orti' and Maya hieroglyphic writing, Ph.D., Department of Anthropology, University of Texas at Austin.

JOHANNESSEN Carl L.

1982 "Domestication process of maize continues in Guatemala", Economic botany, 36 (1), p. 84-99.

Justeson John S., Norman William M., CAmpbell Lyle and Terrence Kaufman

1985 "The origin of Mesoamerican writing", in John S. Justeson, William M. Norman, Lyle Campbell and Terrance Kaufman (eds.), The foreign impact on Lowland Mayan language and script, Middle American Research Institute (Publication, $\mathrm{n}^{\circ}$ 53), Tulane University, New Orleans, p. 31-37.

KNAB Timothy J.

1986 "Metaphors, Concepts, and Coherence in Aztec", in Gary Gossen (ed.), Symbol and meaning beyond the closed community: essays in Mesoamerican ideas (edited by Richard M. Leventhal and J. Jorge Klor de Alva, Studies on 
Marking time among the Ch'orti' Maya: an expressive act of culture

Culture and Society), Institute for Mesoamerican Studies, The State University of New York, Albany, vol. 1, p. 45-55.

LEÓN-Portilla Miguel

1988 [2 éd.] Time and reality in the thought of the Maya, University of Oklahoma Press, Norman.

LeVI-Strauss Claude

1966 The savage mind, Weidenfeld and Nicholson, London.

LÓPEZ García Julián

2003 Ideología y símbolos en la comida indígena guatemalteca. Una etnografía de la culinaria maya-ch'orti', Abya-Yala, Quito.

LÓPEZ GARCíA Julián

2010 La lluvia en la mitología y el ritual maya ch'orti', Cholsamaj, Guatemala.

LóPEz García Julián and Brent Metz

2002 Primer Dios: Etnografía y cambio social entre los mayas ch'orti's del oriente de Guatemala, Magna Terra (Guatemala).

McSweEnEy Kendra

1995 "The cohune palm (Orbignya cohune, Arecaceae) in Belize: a survey of uses", Economic botany, 49 (2), p. 162-171.

Metz Brent

2006 Ch'orti'-Maya survival in Eastern Guatemala: indigeneity in transition, University of New Mexico Press, Albuquerque.

NILSSON Martin

[1920] 1960, Primitive time reckoning, second edition, University Press, Oxford.

Palma Ramos Danilo A.

2001 Así somos y así vivimos: los ch'orti', Universidad Rafael Landivar, Guatemala. Rice Prudence M.

2008 "Time, power, and the Maya", Latin American Antiquity, 19 (3), p. 275-298.

SCHELE Linda and David FreIDEL

1990 A forest of kings: the untold story of the ancient Maya, William Morrow and Company, New York.

Stone Andrea J.

1995 Images from the underworld: Naj Tunich and the tradition of Maya cave painting, University of Texas Press, Austin.

StUART David

2011 The order of days: the Maya world and the truth about 2012, Harmony Books, New York.

Stuart David, Stephen D. Houston and John Robertson

1999 "Recovering the past: Classic Maya language and Classic Maya gods", in Notebook for the XXIIIrd Maya Hieroglyphic Forum at Texas, University of Texas at Austin, Austin.

TATE Carolyn E.

1992 Yaxchilan: the design of a Maya ceremonial city, University of Texas Press, Austin. 
Kerry HulL

\section{TEDLOCK Barbara}

1982 "Sound, texture and metaphor in Quiché Maya Ritual Language", Current Anthropology, 23 (3), p. 269-272.

VAPNARSKY Valentina

2016 "No Escape from the Future. Temporal Frames and Prediction in Yucatec Maya”, in Zlatka Guentchéva (ed.), Aspectuality and Temporality: Theoretical

Vogt Evon Z. and Empirical Issues, John Benjamins, p. 643-678.

1969 Zinacantan. A Maya community in the highlands of Chiapas, Belknap (Harvard University Press), Cambridge (MA).

WichmanN Søren

1999 A Ch'orti' Morphological Sketch. Unpublished manuscript in possession of author. WisDom Charles

1950 Materials on the Ch'orti' language [on-line], Microfilm Collection of Manuscripts on Middle American Cultural Anthropology, 28, (transliterated and computerized by Brian Stross), http://www.utexas.edu/courses/stross/ chorti/, Accessed on March 12, 2015.

ZENDER Mark

2014 "On the reading of three Classic Maya portrait glyphs", The PARI Journal, $15(2)$, p. $1-14$. 